\title{
ПУБЛІЧНИЙ ВИСТУП ЯК МОВЛЕННСВИЙ ЖАНР РИТУАЛЬНОЇ ПОЛІТИЧНОЇ КОМУНІКАЦІї: ТРАНСФОРМАЦІЯ НОВОРІЧНОГО ЗВЕРНЕННЯ В УКРАЇНСЬКІЙ ПРЕЗИДЕНТСЬКІЙ РИТОРИЦІ (на матеріалі новорічних привітань Петра Порошенка)
}

\author{
НАТАЛІЯ КОНДРАТЕНКО \\ Одеський національний університет імені I. І. Мечникова, Одеса - Україна \\ kondr_nat@ukr.net; ORCID: 0000-0002-9589-7716 \\ WYSTĄPIENIE PUBLICZNE JAKO GATUNEK RYTUALNEJ \\ KOMUNIKACJI POLITYCZNEJ: TRANSFORMACJA \\ NOWOROCZNEGO ORĘDZIA DO NARODU W UKRAIŃSKIEJ \\ RETORYCE PREZYDENCKIEJ \\ (na materiale noworocznych orędzi Petra Poroszenki)
}

\author{
NATALIA KONDRATENKO \\ Odeski Uniwersytet Narodowy imienia Ilji Miecznikowa, Odessa — Ukraina
}

\begin{abstract}
STRESZCZENIE. W artykule zbadano jeden $\mathrm{z}$ gatunków dyskursu politycznego orędzie noworoczne stanowiące rytuał werbalnej komunikacji politycznej. Określono strukturalno-kompozycyjne, semantyczne i lingwopragmatyczne cechy orędzia noworocznego, prześledzono dynamikę przemówień świątecznych prezydenta Petra Poroszenki. Celem artykułu jest określenie głównych tendencji $\mathrm{i}$ zmian $\mathrm{w}$ obrębie gatunku orędzia noworocznego odzwierciedlonych w przemówieniach świątecznych obecnego prezydenta Ukrainy P. Poroszenki. Szczegółowe kwestie poruszane $\mathrm{w}$ artykule to: zdefiniowanie strukturalnych i semantycznych cech przemówień noworocznych, a także przeanalizowanie głównych zmian $\mathrm{w}$ ich formie $\mathrm{i}$ treści. Materiał opracowania stanowiły teksty wystąpień noworocznych P. Poroszenki w latach 2015-2018. Udowodniono, że struktura orędzi noworocznych składa się z trzech następujących po sobie części: retrospektywnej, prospektywnej oraz życzeń. Rytualne sformułowania zawierają nazwy adresatów w odniesieniu do przynależności narodowej, państwowej, więzów rodzinnych. Pod względem semantycznym przemówienia noworoczne koncentrują się
\end{abstract}


wokół aktualnej sytuacji w kraju oraz obietnic pozytywnych zmian w kolejnym roku. Koncepcyjne markery leksykalne to „ukraiński”, ,jedność”, „naród” i „rozwój”. Można zaobserwować tendencje do wydłużania części retrospektywnej i skracania części prospektywnej (zarówno pod względem objętności, jak i treści), preferowania nazewnictwa związanego z narodowością i państwem, dominowania rytualnych sformułowań i treści patriotycznych, nasilania się semantyki religijnej, w szczególności chrześcijańskiej, redukcji elementów międzynarodowych i orientacji na politykę europejską, pozytywnego oceniania, wzmacniania egocentryzmu mówiącego (nadawcy). Poruszono problemy konceptualizacji, semantyki i lingwopragmatyki orędzi noworocznych, zareprezentowano wyniki badań nad dynamiką przemówień noworocznych w dyskursie politycznym.

Słowa kluczowe: dyskurs polityczny, gatunek mowy, orędzie noworoczne, retoryka prezydencka, dynamika gatunku mowy

\title{
PUBLIC SPEECH AS A SPEECH GENRE OF RITUAL POLITICAL COMMUNICATION: TRANSFORMATION OF NEW YEAR'S SPEECHES IN THE UKRAINIAN PRESIDENTIAL RHETORIC (case study of Petro Poroshenko's new year's speeches)
}

\author{
NATALIIA KONDRATENKO
}

Odesa I. I. Mechnikov National University, Odesa - Ukraine

\begin{abstract}
The article sets out to investigate one of the speech genres of political discourse New Year's greetings as a verbal representations of ritual political communication. The structural and compositional, semantic and linguistic and pragmatic features of New Year's greetings are determined. The dynamics of New Year's appeals to the Ukrainian people in the presidential rhetoric of Petro Poroshenko is traced out. The article aims at tracing main trends in the genre of New Year's greeting reflected in the speeches of the actual Ukrainian President Petro Poroshenko, this aim leading to the following objectives: to determine structural and semantic features of the genre of New Year's greetings, to analyze texts of greetings and to follow the main modifications of the genre at the level form and content. The corpus of the study comprises texts of New Year greetings by Petro Poroshenko for the period from 2015 to 2018. It is proved that New Year's greetings are based on the three-component structure with the fixed order of the following parts: retrospective, prospective and optative; in ritual formulas they contain names of addressees according to their nationality, family ties and statehood; semantic focus is on characterizing the current situation in the country and promising positive changes in the next year; lexical markers of the conceptual core of the speeches are tokens "Ukrainian", "unity", "people" and "development". We observe a tendency to increase the retrospective part and decrease the prospective one; giving preference to nominations on national and state grounds; domination of patriotic ritual formulas and patriotic content; the strengthening of religious semantics, in particular Christian; reduction of international components and orientation towards European politics; propensity to positive evaluations; strengthening speaker egocentrism.The problems of conceptualization, semantics and linguistic pragmatics of New Year's greetings are presented, generalizations on the genre dynamics of New Year's appeals in the political discourse are elucidated.
\end{abstract}

Key words: political discourse, speech genre, New Year's speech, presidential rhetoric, genre dynamics 
ослідження ритуальних жанрів політичного дискурсу (далі - ПД) заслуговує на увагу з огляду на домінування фатичного спілкування в публічному комунікативному просторі. Виголошення публічних промов у ритуальних ситуаціях урочистих святкувань, річниць або сумних подій є невід'ємним компонентом політичної комунікації: політики беруть активну участь у ритуальних заходах та виголошують ритуальні промови 3 потужним етикетним складником. Політична комунікація характеризується „публічністю, одновекторністю - скеруванням від мовця до адресата, нестабільністю й невизначеністю аудиторії' [Zheltukhina etc 2018: 642] (переклад автор. - Н. К.). Особливе місце серед ритуальних виступів в українському ПД належить новорічному привітанню Президента, оскільки ця подія набула для реципієнтів знакового характеру й здебільшого сприймається як обов'язкова частина святкування Нового року. Традиція вітати народ напередодні новорічних свят не є винаходом українських політиків, вона мала місце й за радянських часів, а також поширена в США та країнах Європи. Проте за часів незалежності цей ритуальний жанр зазнав певних трансформацій на структурному й змістовому рівнях, зважаючи на особистості політиків-ораторів та загальні політичні умови в країні, що потребує грунтовного аналізу та визначає актуальність цієї наукової розвідки.

Останнім часом жанровій диференціації політичної комунікації приділяють увагу й зарубіжні (А. Баранов, Е. Будаєв, О. Іссерс, Ю. Караулов, А. Чудінов, О. Шейгал та ін.), і українські (О. Билінська, Ф. Бацевич, Н. Петлюченко, Л. Славова, Л. Стрій та ін.) лінгвісти. Ритуальні жанри ПД ставали предметом дослідження в аспекті інституційної комунікації (В. Карасик) та ії фатичного різновиду (Т. Винокур). В українському мовознавстві ритуальну політичну комунікацію грунтовно висвітлює Л. Стрій у дисертації, а жанр новорічного привітання розглядають українські й зарубіжні дослідники (А. Битко, В. Варавкіна, А. Зуйковська, В. Кашпур, Н. Кондратенко, В. Ослопова та ін.). У ранніх своїх працях авторка цієї розвідки зосереджувала увагу на загальних принципах структурно-семантичного аналізу жанру новорічного привітання [Кондратенко 2007a: 302-306] та порівнювала новорічні привітання українських, російських і білоруських президентів [Кондратенко 2007б: 40]. Однак комплексного дослідження новорічних привітань українських президентів, зокрема Петра Порошенка, в українському мовознавстві ще немає.

Мета цієї статті - простежити основні тенденції й зміни в жанрі новорічного привітання, віддзеркалені у виступах українського Президента П. Порошенка; завдання - визначити структурно-семантичні особливості жанру новорічного привітання, проаналізувати тексти привітань та простежити основні модифікації жанру на рівні форми й змісту. Матеріалом дослідження слугували тексти новорічних привітань П. Порошенка за період з 2015 до 2018 років. 
Жанр новорічного привітання належить до ритуальних, в основі яких мовленнєвий акт етикетного типу. Л. Стрій зазначає, що на структурно-композиційному рівні функціюють рамкові компоненти: конгратуляційна та констатувальна частини, оптативний складник, а на змістовому рівні привітання „пов'язане з урочистими подіями в житті або суспільства, або соціально значущої особи. За інтенцією привітання передбачає виконання етикетної функції - власне привітання - та елементи самопрезентації мовця як уважного, небайдужого політика" [Стрій 2015: 92]. На лінгвопрагматичних параметрах новорічного привітання наголошує й В. Варавкіна, яка фіксує наявність у цьому жанрі „власної історії, комунікативної мети, чітких вимог до образу адресата, адресанта, інформаційного приводу й опосередкованості зв'язку" [Варавкина 2011: 161] (переклад автор. - Н. К.). А. Битко конкретизує комунікативну мету новорічного звернення: „Спільною ознакою всіх звернень $\epsilon$ наявність узагальненої комунікативної мети, яка полягає в дотриманні традицій щорічного привітання 3 Новим роком, наголошенні на найбільш знакових подіях минулого року та плануванні майбутнього" [Битко 2014: 167]. Дослідниця пропонує визначати специфіку цього жанру за політичною ситуацією в країні. Авторка цієї наукової розвідки зазначає у своїх працях, що конституентами новорічного привітання $є$ ритуальні компоненти: подієвість, часова й локальна зумовленість, закріплена форма й перформативний характер [Кондратенко 2014: 410], що й мотивує специфіку цього жанру президентської риторики. С. Потапенко наголошує на необхідності врахування саме лінгвопрагматичних чинників текстотворення ритуальних політичних текстів, виокремлюючи чотири стадії аналізу - дослідницьку, диспозиційну, ілокутивну та перформативну [Potapenko 2016: 14].

П. Порошенко як Президент виголошує новорічне привітання з 2015 р.; його виступи характеризуються стислістю й змістовністю. У першому привітанні новообраний очільник держави звертався до багатонаціональної аудиторії, звідси й виголошення оптативної частини трьома мовами українською, російською і кримськотатарською. Структуру привітання 2015 р. формують стисла характеристика подій минулого року, ушанування загиблих воїнів. На рівні змісту можна виділити заклики до об'єднання: “ $\epsilon \partial u$ на країна!” - “Единая страна!” - “Бір дєвлєт!”. При цьому актуалізовано функцію інтеграції народу як одну з основних у ритуальних політичних текстах, що полягає в “утвердженні єдності нації” [Шейгал 2004: 248]. Привітання побудовано як протиставлення важкого минулого року, що згуртував народ перед зовнішньою загрозою, та обіцянок зробити наступний рік роком реформ і європейських прагнень країни. У ретроспективній частині подано стислу характеристику минулорічних подій як здебільшого трагічних для України (зовнішня агресія, війна, утрати), у проспективній — відсутні плани 
та обіцянки, але згадано про згуртованість і єдність, що стануть передумовою для майбутніх змін у країні.

На рівні ритуальних етикетних формул Президент уникає вживання звертань за національною ознакою, а послуговується формулюванням Дорогі, рідні співвітчизники! На мовному рівні переважають консолідовані форми звернення до адресата 3 наданням переваги займенниково-дієслівним формам множини - ми, наш, нас тощо (11 уживань), натомість форми 1-ої особи однини є нечисленними (4 уживання), поєднані 3 формами множини та вказують передусім на мовленнєву діяльність мовця та сполучені з формами множини: Сьогодні ж бажаю всім нам насамперед довгоочікуваного, тривалого миру. У цьому привітанні репрезентовано й характерну для промов П. Порошенка рису - використання інтертекстуальних елементів, зокрема паспортизованих цитат, що увиразнює інтелектуальний складник тексту, напр.: Хай збудеться пророитво Шевченка: „I на оновленій землі врага не буде супостата, а буде син, і буде мати, і будуть люди на землі!”. Цитоване висловлення є прецедентним, тому орієнтовано на масового адресата. Стилістичні мовні засоби експресивного характеру обмежено метафорами (старт реформ) та фразеологізмами (ми стали нерозлийвода). Ритуальні компоненти охоплюють мовленнєві акти привітання й побажання, що експлікує прагматичний характер новорічного привітання: Ян 'и йилиниз хайирли олсун, азіз ватандашлар! С Новым годом, дорогие соотечественники! 3 Новим роком, дорогі співвітчизники! Звернімо увагу на порядок подання привітань: спочатку кримськотатарською мовою, потім російською й лише наприкінці українською, що визначає пріоритети мовця в зверненні до цільової аудиторії.

На рівні змісту експліковано концепти 'мир' (незалежність, життя), 'Україна' (країна, Вітчизна, Батьківщчина), 'єдність' (згуртованість, разом, yci), 'ворог' (агресор), 'народ’ (ми, нація), напр.: Перш ніж наповнити келихи, за мить до дванадияти ударів, які сповістять про Новий рік, і перед тим, як заспівати ,Ще не вмерла”, разом, всією Украӥною, вщануймо пам'ять воїнів, які віддали свос життя за Україну, і пам'ять мирних громадян, які загинули $з$ вини агресора! На семантичному рівні окреслено ситуацію в країні, зокрема узагальнено й неперсоніфіковано зосереджено увагу на війні та агресії; змістовим центром і визначальною ідеєю привітання є 'єдність країни', а конкретні плани, як і здобутки, не окреслені. Новорічне привітання 2015 р. було найкоротшим серед усіх виступів Президента.

У привітанні 2016 р. фіксуємо зміни на всіх рівнях тексту. Зокрема, на композиційному рівні значно домінує перша структурна частина, що має звітний характер. За зразком попереднього тексту привітання ініціальна частина містить подяку воїнам та твердження стосовно об'єднання українського народу, однак уже переважають позитивні характеристики й прогнози майбутніх подій. Президент характеризує минулий рік і перелічує досягнення 
країни, серед яких називає зупинення агресії Росії, відкриття зони торгівлі 3 Свросоюзом, створення антикорупційних органів тощо, напр.: I символічно, що саме напередодні свят ми вибороли кілька важливих рішень Свросоюзу. Наступного року впаде паперова завіса між Украӥною та Свросоюзом. Друга частина — плани на наступний рік — грунтується на висвітленні досягнень країни за попередній рік, однак не виокремлена у виступі. Структурно в цьому привітанні виділяємо не дві, а три частини, кожна 3 яких відмежована від попередньої звертанням або патріотичним вигуком: ретроспективна частина розпочинається після звертання до адресата, проспективна - після вигуку Героям - слава!, а оптативна - знову після звертання. Ритуальні формули також змінилися: на відміну від попереднього привітання, ужито звертання Дорогі, piдні українці! на початку й у кінці промови, що актуалізує семантику державництва. Крім того, з'являється й ритуальна формула Слава Україні! Героям слава!, що виконує текстотвірну роль у привітанні, оскільки членує його на відповідні змістові блоки.

На концептуальному рівні фіксуємо концепти 'українець' (людина, воїн, волонтер, працівник), 'Україна' (країна, народ), 'Свропа' (Свросоюз, міжнародні партнери, європейський), 'війна' (наступ, агресія, штурм, Росія, Москва), що вказує на актуалізацію євроорієнтації зовнішньої політики та посилення патріотичних ідей у привітанні П. Порошенка, напр.: Україна буде європейською, сильною, єдиною! На семантичному рівні фіксуємо й опозицію Україна - Росія, що була репрезентована в попередньому привітанні, але в цьому увиразнена більшою мірою. Так посилено й семантику патріотичності і наголошено на ролі українців та України у світовій політиці.

У привітанні також наявні інтертекстуальні елементи - це паспортизована цитата з вірша I. Франка: „Я бажаю, щоб в здоров ю, / в мирі, з братньою любов'ю, / відтепер ішов нам час. / Щирій праці Бог поможе! / Дай вам Боже все, щуо гоже!'” Ці слова Івана Франка не залишають сумніву, щзо все у нас буде добре! Весь текст звернення виголошений українською мовою, без використання інших мов народу України. Комунікативну позицію адресанта, виражену займенниково-дієслівними граматичними формами, подано як узагальнену 3 актуалізацією семантики консолідації політика з народом, у тексті відсутні висловлення $з$ формами 1-ої особи однини. У такий спосіб мовець, який вітає масового адресата, наголошує не на власній ролі в політичних процесах минулого року, а насамперед на спільних діях усього українського народу. Крім того, обсяг тексту промови (порівняно з попереднім роком) був значно більшим.

Привітання П. Порошенка 32017 р. уперше починалося не 3 характеристики кризи в країні та подяки українським воїнам, а зі згадки про християнські свята Святого Миколая й Водохреща. Позитивнооцінна семантика експлікована на початку промови: Приводів для оптимізму сьогодні більше, ніж рік тому. Так, перша частина привітання містить перелік фактів, що 
прокоментовані як здобутки України: незалежність від Росії, економічне зростання, зміцнення обороноздатності, перемога Джамали на Євробаченні тощо. Замість загальних успіхів наведено перелік конкретних подій і фактів, якими пишається країни. Проте перехід від звіту до блоку обіцянок і планів здійснено логічно: мовець одразу починає характеризувати наступний рік як столітню річницю Української національної революції, тому вказує на відповідні очікування. Серед планів зазначено лише зближення з Свросоюзом і НАТО. Подяка українським воїнам і агресія Росії загадані лише після обох обов'язкових частин промови: Славні украӥнські воїни! Уся краӥна дякує вам за те, щзо даруєте нам цүю мирну святкову ніч. За те, щзо гарантуєте захист у новому рочі. Від імені всієї Украӥни вітаю вас, наші співвітчизники, брати та сестри в Криму, Севастополі та окремих районах Донеччини та Луганщині. Російська окупація - тимчасова. Ми обов'язково об'єднаємося. Після цього простежуємо лише мовленнєві акти побажання й власне привітання.

Ритуальні формули, повторені з минулорічного привітання: звертання Дорогі украӥнці! та на завершення - вигук Слава Україні!, усередині виступу звертання відсутні. Однак у частині звернення до українців на окупованих територіях використано й звертання Наші співвітчизники й брати та сестри!, що розширює ритуальний компонент виступу. На концептуальному рівні визначаємо вербалізацію концептів 'українець' (співвітчизник, брат), 'народ’ (краӥна, ми), ‘єдність' (єдиний, разом), ‘успіх' (зростання, збільшення), 'перемога' (подолати, адаптувати, відновити, зміцинтти), що вказує на домінування позитивної оцінки в промові та відсутність протиставлень аксіологічного типу. Лексеми, що репрезентують концепти 'війна' (агресія, руйнування, загроза, воювати) і 'ворог’ (Росія, агресор), репрезентовані меншою мірою. У привітанні цього року відсутні інтертекстуальні елементи.

Аналізований текст побудовано за принципом синтаксичного паралелізму, актуалізовано модель $M u+V_{p l}$ : Мu подолали...; Mu адаптували...; напр.: $M u$ зміцнили нашу обороноздатність. Композиційним центром слугує твердження про особливість прийдешнього року, після якого наведена частина проспективного характеру, що протиставлена ретроспективній не лише за змістом, а й на мовному рівні: узагальнені граматичні форми множини в займенниково-дієслівних конструкціях змінено на форми 1-ої особи, напр.: $Я$ зробив висновки. Чужих помилок - не повторю. Та й іниим - не дам, а на синтаксичному рівні замість періодичного мовлення з конструкціями синтаксичного паралелізму вжито здебільшого фрагментовані та лакунарні речення. Зазначмо, що привітання 2017 р. суттєво відрізняється й від попередніх, i від наступних як на структурному, так і на семантичному рівнях.

У новорічному зверненні 2018 р. П. Порошенко повертається до структурно-семантичного типу виступу, відомого за попередніми роками, коли ініціальна частина промови містить подяку українським воїнам, повідомлення 
про звільнення військових з полону, згадку про Крим і Донбас та засудження російської агресії: Із глибокою потаною привітаймо украӥнських воїнів. Вони надійно тримають оборону на східних рубежах. А ми й надалі будемо змічнювати нову армію, - наму гордість $і$ нашу славу. Ретроспективна частина 3 кожним роком збільшується й за обсягом, і за семантичним наповненням, що цілком зрозуміло, оскільки Президент примножує здобутки країни під своїм керівництвом: у цьому разі фіксуємо розгорнуті коментарі щодо допомоги США, отриманого “безвізу”, рішення Стокгольмського арбітражу, подовження санкцій проти Росії, — звітна частина становить більше половини загального тексту привітання. Другий компонент основної частини — плани на наступний рік - обмежено обіцянками економічного зростання без конкретики: У новому роиі Уряд має прискорити темпи зростання. Потрібне підвищення рівня життя, відчутне для більшості украӥнців. Ритуальні формули звертання до адресатів незмінні: на початку звертання Дорогі украӥнці!, а в тексті - Брати і сестри! - стосовно мешканців окупованих територій. Завершується привітання закликом Слава Україні!.

Щодо семантики промови зазначимо, що домінують концепти 'українець' (співвітчизник, воїн, брати й сестри), 'Європа' (Свросоюз, Стокгольмський арбітраж), 'розвиток' (рух, відновлення, зростання, піднесення). Загальна семантика виступу П. Порошенка $є$ позитивною на аксіологічному рівні, що увиразнено на лексичному рівні маркерами оцінного характеру субстантивного типу — пошана, гордість, слава, надія, відновлення, зростання, підвищення, єдність, оптимізм, віра тощо. Семантика цього привітання здебільшого пов'язана із загальними позитивними оцінками чинної ситуації та обіцянками змінити все на краще, при цьому майже не згадуються нагальні проблеми країни. Знову фіксуємо й інтертекстуальний елемент - паспортизовану цитату: Для иього, як вчив владика Любомир Гузар, нам слід молитися так, ніби все залежить від Бога, але пращювати так, ніби все залежить від нас. Вибір для цитування вислову релігійного діяча, представника української Греко-католицької церкви, указує на відновлення політиком пріоритетності релігійно-етичних цінностей і відповідної християнської конфесії. У цьому привітанні використано й стилістичні фігури та політичну метафорику: У тих, хто хоче підпалити хату зсередини, — слід забирати сірники. А по тих, хто нападатиме на нас ззовні, - навпаки, відкривати вогонь. Тут використано прийом антитези та синтаксичного паралелізму, що поєднано з метафорами й порівняннями, тому створюється особлива образність виступу, раніше відсутня у промовах Президента. На лінгвопрагматичному рівні вперше з'являється комісив з декларативною частиною: Як Президент - забезпечу політичні умови, необхідні для економічного піднесення. І мовленнєві акти, подані від імені мовця, є не лише ритуальними, а й репрезентативними й комісивними. Займенниково-дієслівні конструкції також зазнали змін: крім традиційного протиставлення ми (7 ужи- 
вань) та я (5 уживань), натрапляємо на свій (2 вживання) та вас (1 вживання). Прокоментуємо останнє: За все, чого краӥна досягла, - величезна подяка кожному з вас. Це результат спільної праці. Тут узагальнення здійснено через дистанціювання від адресата, що раніше не було помічено в промовах П. Порошенка. Розширення дейктичного поля трактуємо як послаблення семантики інтеграції, характерної для ритуальних текстів.

Узагальнимо структурно-семантичні особливості й зміни, наявні в новорічних привітаннях П. Порошенка. За структурою новорічні привітання Президента України є трикомпонентними із закріпленим порядком слідування частин: ретроспективна, проспективна й оптативна. Відповідно до ритуальних формул вони містять найменування адресатів за ознаками національності (украӥнці), родинних зв’ язків (брати й сестри) і державності (співвітчизники). За семантикою змісту привітання відзначаються домінуванням характеристики чинної ситуації в країні та наявністю значної кількості обіцянок здійснити позитивні зміни в наступному році. Вербалізаторами концептуального ядра промов є лексеми українець, єдність, народ і розвиток. Простежуємо зміни на всіх рівнях тексту промов: тенденцію до збільшення ретроспективної частини й зменшення проспективної (і за обсягом, і за змістом); надання переваги номінаціям за національною й державницькою ознакою; домінування патріотичних ритуальних формул і патріотичного змісту; посилення релігійної семантики, зокрема християнської; зменшення інтернаціональних компонентів та орієнтацію на європейську політику; схильність до позитивних оцінок; посилення егоцентризму мовця. Отже, Петро Порошенко впродовж років президентства, виголошуючи новорічні промови, демонструє патріотичні настрої, наголошує на єдності народу перед зовнішньою агресією, актуалізує здобутки й підкреслює власну роль у цих досягненнях, підтримує національні й релігійні (християнські) цінності.

\section{Список використаної літератури}

Битко А. С., Новорічне звернення президента як ритуальний жанр політичного дискурсу, [в:] „Соціальні технології: актуальні проблеми теорії та практики”, 2014, вип. 63, c. $165-172$.

Варавкина В. Ю., Новогоднее обращение главы государства: жанровая специфика и лингвокогнитивное моделирование образа адресат, дис. ... канд. филол. наук, Омск 2011.

Кондратенко Н. В., Новогоднее обращение как ритуальный жанр политического дискурса: макроструктурные компоненты и средства их выражения, [в:],„омпьютерная лингвистика и интеллектуальные технологии", 2007a, с. 302-306.

Кондратенко Н. В., Специфіка новорічного звернення як ритуального жанру політичного дискурсу, [в:] Одеська лінгвістична школа: координати сучасних пошуків, Одеса: Поліпринт, 2014, с. 409-416. 
Кондратенко Н. В., Украӥнський політичний дискурс: текстуалізація реальності, Одеса: Чорномор'я, $2007 б$.

Стрій Л. І., Ритуальні жанри украӥнського політичного дискурсу: структурно-семантичний і лінгвопрагматичний аспекти, дис. ... канд. філол. наук, Одеса 2015.

Шейгал Е. И., Семиотика политического дискурса, Москва: Гнозис, 2004.

Zheltukhina M., Busygina M., Merkulova M., Zyubina I., Buzinova L., Linguopragmatic aspect of modern communication: main political media speech strategies and tactics in the USA and the UK, [в:] „XLinguae”, 2018, vol. 11, issue 2, p. 639-654.

Potapenko S., Cognitive rhetoric of effect: energy flow as a means of persuasion in inaugurals, [в:] „Topics in Linguistics”, 2016, № 17 (2), p. 12-25.

\section{Spysok vykorystanoi literatury [References]}

Bitko A. S., Novorichne zvernennia prezydenta yak rytualnyi zhanr politichnoho dyskursu [New Year's Address by the President as a Ritual Genre of Political Discourse], [v:] „Sotsialni tekhnolohii: aktualni problemy teorii ta praktyky", 2014, vyp. 63, s. 165-172.

Varavkina V. Yu., Novogodnee obrashchenie glavy gosudarstva: zhanrovaya specifika $i$ lingvokognitivnoe modelirovanie obraza adresata [New Year's Address by the Head of State: Genre Specificity and Linguocognitive Modeling of the Image of the Addressee], dis. ... kand. filol. nauk, Omsk 2011.

Kondratenko N. V., Novogodnee obrashchenie kak ritual'nyj zhanr politicheskogo diskursa: makrostrukturnye komponenty i sredstva ix vyrazheniya [New Year's Appeal as a Ritual Genre of Political Discourse: Macrostructural Components and Their Means of Expression], [v:] „Kompyuternaya lingvistika i intellektual'nye texnologii”, 2007a, s. 302306.

Kondratenko N. V., Spetsyfika novorichnoho zvernennia yak rytualnoho zhanru politychnoho dyskursu [Specificity of New Year's Appeal as a Ritual Genre of Political Discourse], [v:] Odeska linhvistychna shkola: koordynaty suchasnykh poshukiv, Odesa: Poliprint, 2014, s. 409-416.

Kondratenko N. V., Ukrainskyi politychnyi dyskurs: tekstualizatsiia realnosti [Ukrainian Political Discourse: Textualization of Reality], Odesa: Chornomoria, 2007b.

Strii L. I., Rytualni zhanry ukrainskoho politychnoho dyskursu: strukturno-semantichnyi $i$ linhvopragmatychnyi aspekty [Ritual Genres of Ukrainian Political Discourse: Structural Semantic and Linguistic and Pragmatic Aspects], dis. ... kand. fílol. nauk, Odesa 2015.

Shejgal O. I., Semiotika politicheskogo diskursa [Semiotics of Political Discourse], Moskva: Gnozis, 2004.

Zheltukhina M., Busygina M., Merkulova M., Zyubina I., Buzinova L., Linguopragmatic aspect of modern communication: main political media speech strategies and tactics in the USA and the UK, [v:] „XLinguae”, 2018, vol. 11, issue 2, p. 639-654.

Potapenko S., Cognitive rhetoric of effect: energy flow as a means of persuasion in inaugurals, [v:] „Topics in Linguistics”, 2016, № 17 (2), p. 12-25. 